Mémoire.

Mots-clés : Angiostrongylose. Nicaragua. Pathologie. Angiostrongylus costaricencis.

\title{
ABDOMINAL ANGIOSTRONGYLIASIS IN NICARAGUA: A CLINICO-PATHOLOGICAL STUDY ON A SERIES OF 12 CASES REPORTS
}

\author{
Z. DUARTE*, ${ }^{* * *}, * * * *$, P. MORERA**, P. N. VUONG***
}

SUMMARY

A retrospective study was done to determine the presence of abdominal angiostrongyliasis in Nicaragua. Twelve cases of this parasitic disease were found among 48 visceral specimens: small intestine, liver and testes. The patients with intestinal lesions presented symptoms of an acute abdomen, and in some instances, a tumor-like mass was palpated in the lower right quadrant. A thickening of the intestinal wall accompanied by necrosis and per- foration were the most important macroscopic findings. One patient with hepatic localisation of Angiostrongylus costaricencis displayed a clinical picture of visceral larva migrans-like syndrome. The chief laboratory findings were leukocytosis and eosinophilia. The histopathological examination showed granulomas and heavy eosinophilic infiltration around the eggs and larvae of $A$. costaricencis. Also, an adult worm was seen in one biopsy.

\section{RÉSUmÉ : Angiostrongylose abdominale au Nicaragua : étude anatomo-clinique. A propos de 12 cas.}

Cette étude rétrospective confirme l'existence de l'angiostrongylose abdominale au Nicaragua. Elle se base sur 48 prélèvements viscéraux : intestin, foie et testicules effectués chez 12 patients. L'atteinte intestinale se révèle par un syndrome abdominal aigu ou parfois par une masse pseudo-tumorale du flanc droit. Elle se caractérise par un épaississement de la paroi intestinale avec nécrose et perforation. L'atteinte hépatique se traduit par un syndrome similaire à celui du larva migrans viscéral Les données biologiques sont représentées par une leucocytose avec hyperéosinophilie. Dans tous les cas, il s'agit histologiquement de lésions granulomateuses centrées par des œufs et des larves d'Angiostrongylus costaricensis. Un ver adulte a été retrouvé dans la lumière d'une artère appendiculaire dans un cas.

\section{INTRODUCTION}

Abdominal angiostrongyliasis (AA), caused by Angiostrongylus costaricensis is a human parasitic disease with wide prevalence in the American continent (Barbosa et al., 1980; Morera et al., 1971; Zambrano, 1973; Zavala et al., 1979). Several species of rodents are the definitive host (Morera, 1970 and 1973; Quintana, 1984; Tesh, 1973) and the gastropod Vaginulus plebeius is the most important intermediate host (Morera 1970 and 1973). Man is an accidental host. Adult worms live in the lumen of the mesen-

* Department of Pathology, Oscar Danilo Rosales Hospital, Léon, Nicaragua.

** Laboratory of Parasitology, School of Medicine, University of Costa Rica, San Jose, Costa Rica.

*** Unité d'Anatomie et de Cytologie Pathologiques, Hôpital Saint-Michel, 33, rue Olivier-de-Serres, F 75015 Paris.

**** Laboratoire de Biologie et Contrôle des Organismes Parasites ( $\mathrm{P}^{\mathrm{r}} \mathrm{Ph}$. Gayral). Faculté de Pharmacie, Université ParisSud, Rue J.-B.-Clément, F 92290 Châtenay-Malabry.

Reprint: Dr. Z. DuARTe, Unité d'Anatomie et de Cytologie Pathologiques, Hôpital Saint-Michel, 33, rue Olivier-de-Serres, F 75015 Paris.

Accepté le: 2 janvier 1992. teric arteries. First stage larvae pass in the rodent faeces and are ingested by slugs. Rats and man become infected by eating the slugs or unwashed vegetables that have been contaminated with the mucus secretions of molluscs containing the infected third stage larvae. Although the human disease has been found in most Central American countries (Loria et al., 1980; Sauerbray, 1977; Sierra et al., 1972), it has not formally been reported from Nicaragua. As environmental conditions in Nicaragua are similar to neighboring countries, this suggests that AA should be present. We consequently set out to confirm its presence in the country and to describe the clinical and pathological picture of the disease.

\section{MATERIAL AND METHODS}

The clinical records from 1979 to 1982 of the Pathology Department of the Oscar Danilo Rosales Arguello Hospital at Léon, Nicaragua, were searched for intestinal, liver and testes biopsies showing granulomatous inflammation with eosinophilic infiltration. All of the original slides from visceral specimens which showed lesions suggestive of AA were re-examined. When a parasitic structure was not clearly evident, indirect immunofluorescence was 
performed with polyclonal rabbit antibody against $A$. costaricensis to search for antigens. This antibody was prepared in Laboratory of Parasitology, National University of Costa Rica, San José, Costa Rica. Clinical information was available in only seven of the confirmed cases. The macroscopic appearance was compiled from the surgeon's notes and the description in the pathologist's report.

\section{RESULTS}

Among the 48 cases suspected, twelve were confirmed as AA. Different developmental stages of $A$. costaricensis were observed in the intestine of eleven patients and in the liver of the twelfth.

\section{A - Clinical findings (Table I)}

The disease was more common in boys less than 12 years old ( 4 cases), and in urban dwellers (6 cases). It developed acutely in five patients and gradually in two. Worms were located in the intestine of six patients, five of whom complained of pain in the right iliac fossa and the sixth patient having diffuse pain. Fever was present in all of the cases, the temperature ranging from $38^{\circ} \mathrm{C}$ to $39^{\circ} \mathrm{C}$. Nausea, vomiting and anorexia occurred in four patients. The physical examination revealed signs of peritoneal irritability in all of the cases, and a tumor-like mass was palpated in the lower right quadrant of three patients. Rectal examination was painful in two cases. In the seventh patient, worms were found in the liver. The patient complained of pain in the abdominal upper right quadrant, fever, nausea, vomiting and anorexia. Palpation was painful and the liver was $10 \mathrm{~cm}$ below the right costal borders. Both these clinical pictures were accompanied by leukocytosis ranging between $10,000-20,000 / \mathrm{mm}^{3}$ and eosinophilia from 9 to $50 \%$.

TABLE I. - Clinical findings in seven patients with $A A$.

\begin{tabular}{ll}
\multicolumn{1}{c}{ Symptoms or signs } & No. of cases \\
\hline Abdominal pain & 7 \\
Fever & 7 \\
Nausea & 5 \\
Vomiting & 5 \\
Anorexia & 5 \\
Abdominal tenderness & 7 \\
Abdominal tumor-like mass & 3 \\
Painful rectal examination & 2 \\
Hepatomegaly & 1 \\
\hline
\end{tabular}

\section{B - Pathological findings (Table II)}

The lesions were observed affecting either a single organ or an intestinal segment or various segments of the intestinal tractus. They were located in the appendix in six cases, in the terminal ileum in two and in the liver in one. In
TABLE II. - Location of lesions at surgery in seven patients with $A A$.

\begin{tabular}{lc}
\hline \multicolumn{1}{c}{ Location } & No. of cases \\
\hline Intestinal & 6 \\
- Appendix & 2 \\
- Terminal ileum & 3 \\
- Appendix, terminal ileum and colon & \\
Extraintestinal & 1 \\
- Liver & \\
\hline
\end{tabular}

the three remaining surgical specimens the lesions were simultaneously seen in the appendix, terminal ileum, cecum and ascending colon.

1 - Macroscopic changes (Table III). In the eleven intestinal specimens, thickening of the wall was the most common finding, attaining $3-4 \mathrm{~cm}$ in four patients. The lumen was reduced in eight cases. Necrosis and perforation were seen in six. Other gross features observed were opacity of the serosa (6 cases) and fibrinous-purulent exudate on the serosa (4 cases). The liver of the twelfth patient showed several small yellowish nodules scattered over the surface.

TABle III. - Macroscopic lesions in twelve patients with $A A$.

\begin{tabular}{lc}
\multicolumn{1}{c}{ Gross findings } & No. of cases \\
\hline Thickening of the intestinal wall & 11 \\
Intestinal stenosis & 8 \\
Necrosis & 6 \\
Intestinal perforation & 6 \\
Opacity of the intestinal serosa & 6 \\
Peri-visceral fibrinous-purulent exudate & 4 \\
Scattered nodules over the liver capsule & 1 \\
\hline
\end{tabular}

2 - Microscopic findings. The histopathological examination of the twelve visceral biopsies revealed a granulomatous inflammatory reaction accompanied by massive eosinophilic infiltration in all the layers of the intestinal wall (Fig. 1) and the periportal spaces of the liver. Areas of necrosis associated with either a granuloma or a thrombosis of the small vessels were seen in all intestinal specimens. Occasionally arteritis were also seen (4 biopsies). Eggs, embryos and larvae were observed inside the granulomas, frequently surrounded by multinucleated giant cells (Fig. 2). In one case, fragments of the adult worm were also found in the lumina of the medium-sized muscular artery (Fig. 3). The morphological characteristics of the different stages of the parasite were typical of $A$. costaricensis in eight biopsies (Fig. 4, 5). Three intestinal biopsies however harbored only degenerated unfertilized eggs. In these cases, as well as the one showing fragments of the 


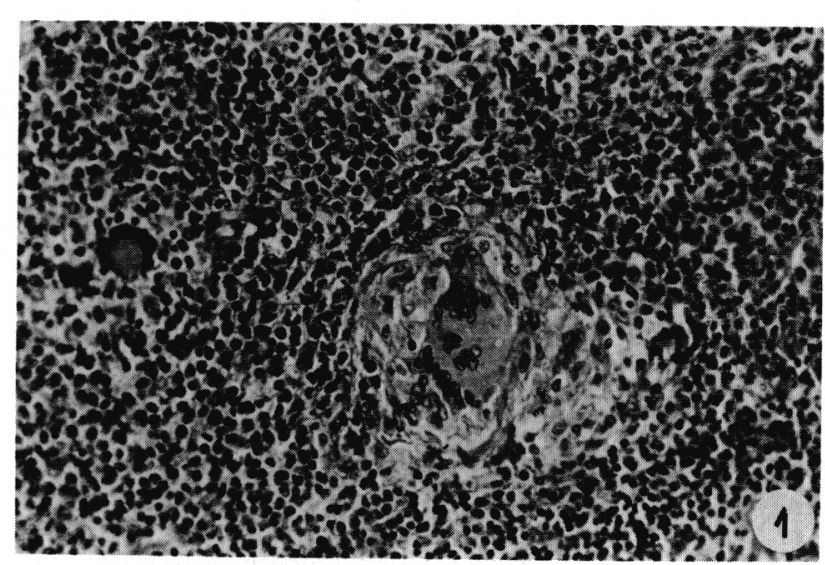

FIG. 1. - Granulomatous inflammation with heavy eosinophilic infiltration and giant multinucleated cells in the submucosa of the appendix. $\mathrm{HE} \times 140$.

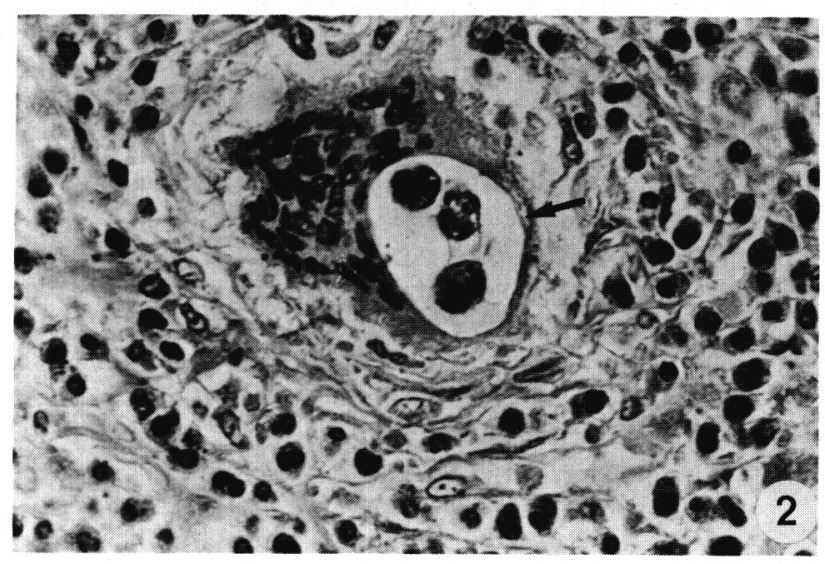

FIG. 2. - First stage larva of $A$. costaricensis, sliced into three segments (arrow), surrounded by a foreign body-type multinucleated cell in the submucosa of the ileum. $\mathrm{HE} \times 400$.

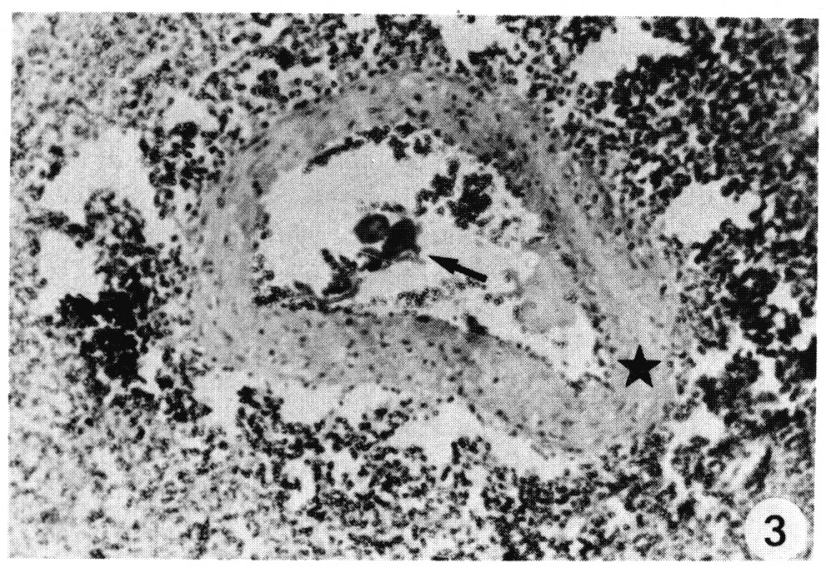

FIG. 3. - Segments of $A$. costaricensis adult worm (arrow) within the lumina of an artery (star) of the appendicular serosa. $\mathrm{HE} \times 100$.

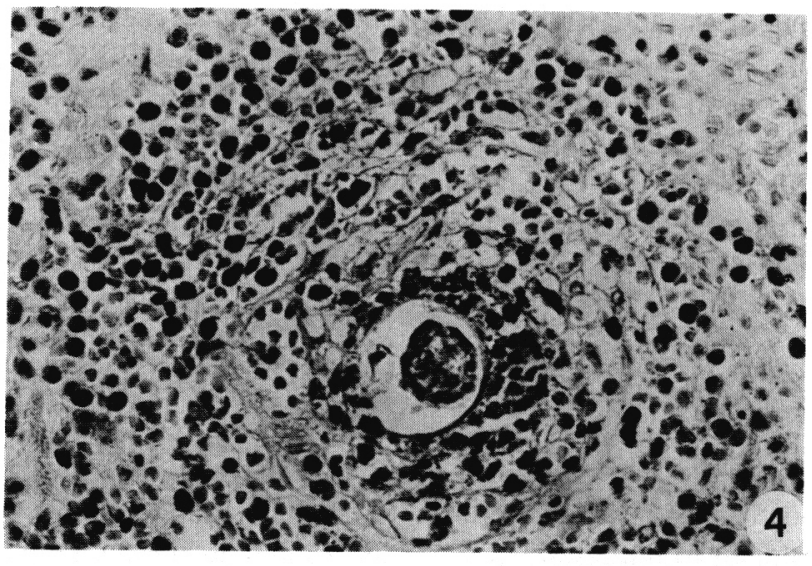

FIG. 4. - Embryonated egg of $A$. costaricencis surrounded by granulomatous inflammation in the submucosa of the ileum. $\mathrm{HE} \times 200$.

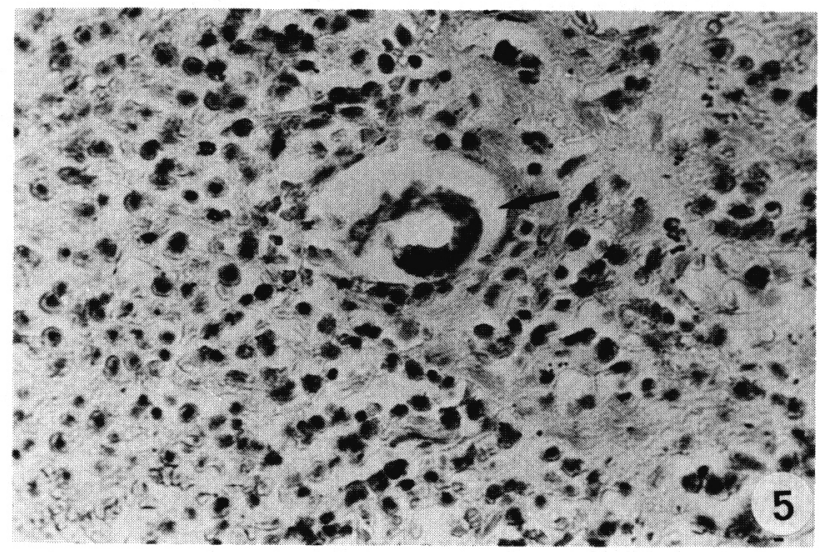

Fig. 5. - First stage larva of $A$. costaricensis (arrow) surrounded by eosinophils and macrophages in the submucosa of the appendix. HE $\times 200$.

adult worm, indirect immuno-fluorescence was used to show the presence of tissular antigens of $A$. costaricensis.

\section{DISCUSSION}

Abdominal angiostrongyliasis is a parasitic disease previously reported only from the American continent. Recently a human autochtonous case has been found in Africa (Kevin et al., 1987). Although one Nicaraguan case of AA was seen in Cuba (Castañeda et al., 1983). This study is the first report of AA in Nicaragua. In man, the adult parasites are usually localized in the mesenteric arteries of the ileo-caeco-colic region (Morera, 1973). Nevertheless erratic localizations in the liver and the testes have been observed. Patients with intestinal lesion may develop a clinical picture which resembles acute appendicitis requir- 
ing surgical treatment (Loria et al., 1980; Robles et al., 1968) or, more frequently, a chronic and mild clinical disease (Morera, 1985). When the liver is affected, the clinical picture is similar to that of visceral larva migrans (Morera et al., 1982). The worms in the spermatic arteries may induce arterial obstruction causing necrosis of the testicular parenchyma (Ruiz et al., 1983). Among the twelve cases reported here, there were eleven with intestinal lesions and one with hepatic injury. The clinical presentation of the intestinal cases was typical of AA and it was comparable to that of the previously reported cases in others Latino-American countries (Barbosa et al., 1980; Loria et al., 1980). The patient with hepatic localisation showed a clinical picture similar to the cases of visceral larva migrans-like syndrome caused by $A$. costaricensis reported in Costa Rica (Morera et al., 1982). Although in the most of the visceral biopsies morphologic features of the parasitic structures were identical to those of $A$. costaricensis (Morera, 1973 and 1982), in only three cases were non-embryonated and fragmented eggs observed. In these cases the histopathologic diagnostic was difficult and indirect immuno-fluorescence-stain was performed to confirm the parasitic nature. Even though all the cases reported here were clinically and pathologically typical of AA, the diagnosis had initially not been made. This misdiagnosis was probably due to a lack of awareness about this entity. In American countries where $A$. costaricencis has been reported, the natural hosts of the parasite are several species of rodents and slugs (Morera, 1970, 1973 and 1985; Quintana, 1984). Both hosts are abundant in rural and urban areas of Nicaragua and live in close proximity to man, providing numerous opportunities of contamination. This suggests that AA could be a serious health problem which is poorly understood in Nicaragua and requires further studies.

Acknowledgments. - The authors would like to express their thanks to Dr. Juan Munquia, Department of Pathology, Oscar Danilo Rosales Arguello Hospital, Nicaragua, for his help in the selection of suspected angiostrongyliasis cases. Thanks are also due to Martha CONEJO and Arnoldo CASTRo, Laboratory of Parasitology, University of Costa Rica, for their technical assistance. This work was supported by the Pan American Health Organisation in Nicaragua.

\section{REFERENCES}

1. Barbosa H., Raick A. N., Magalhaes A. V., Otero P. M. F. : Angiostrongylosis abdominal. Rev. Ass. Med. Brasil, 1980, $26,178-180$.
2. Castañeda C., Gra B., Achon R., Llapar C., Labrada E. : Granulomatosis hépatica y entérica por Angiostrongylus costaricencis. XIV Congreso Latino-Americano de Patología, Habana, Cuba, Noviembre 1983.

3. Kevin Baird J., Neafie R. C., Lanoie L., Connor D. H. : Abdominal angiostrongylosis in an african man: case study. Am. J. Trop. Med. Hyg., 1987, 37, 353-356.

4. Loría R. M., Lobo J. F. : Clinical abdominal angiostrongyliasis. A study of 116 children with intestinal eosinophilic granuloma caused by Angiostrongylus costaricensis. Am. J. Trop. Med. Hyg., 1980, 29, 538-544.

5. Morera P., Ash L. R. : Investigación del huésped intermediario de Angiostrongylus costaricensis (Morera y Céspedes, 1971). Bol. Chileno. Parasitol., 1970, 25, 135.

6. Morera P. : Investigación del huésped definitivo de Angiostrongylus costaricencis (Morera y Céspedes, 1971). Bol. Chileno. Parasitol., 1970, 25, 133-134.

7. Morera P., Céspedes R. : Angiostrongylosis abdominal. Una nueva parasitosis humana. Acta Medica. Cost., 1971, 14, 159-173.

8. Morera P. : Life history and redescription of Angiostrongylus costaricensis. Am. J. Trop. Med. Hyg., 1973, 22, 613621.

9. Morera P., Perez F., Mora F. : Visceral larva migrans-like syndrome caused by Angiostrongylus costaricensis. Am. J. Trop. Med. Hyg., 1982, 31, 67-70.

10. Morera P. : Abdominal angiostrongyliasis: a problem of public health. Parasitol. Today, 1985, 1, 173-175.

11. Quintana A. : Angiostrongylus costaricensis en roedores. Tésis de Grado. Facultad de Ciencias Médicas, Universidad de San Carlos, Guatemala 1984, 43 p.

12. Robles G., Loría R., Lobo F., Robles A., Valle S. : Granuloma eosinofílico parasitario intestinal. Rev. Med. Hosp. Nal. Niños, 1968, 3, 67-80.

13. Ruiz P. J., Morera P. : Spermatic artery obstruction caused by Angiostrongylus costaricensis. Am. J. Trop. Med. Hyg., 1983, 32, 1958-1959.

14. Sauerbrey M. : A precipitin test for the diagnosis of human abdominal angiostrongyliasis. Am. J. Trop. Med. Hyg., 1977, 26, $1156-1158$.

15. Sierra E., Morera P. : Angiostrongylosis abdominal. Primer caso humano encontrado en Honduras. Acta Med. Cost., 1972, 15, 95-99.

16. Tesh R. B., Ackermann L. J., Dietz W. H., Williams J. A. : Angiostrongylus costaricensis in Panama. Prevalence and pathologic findings in wild rodents infected with the parasite. Am. J. Trop. Med. Hyg., 1973, 22, 348-356.

17. Zambrano Z. : Ileocolitis pseudotumoral eosinofílica de origen parasitario. Rev. Latino-Am. Patol., 1973, XII, 43-50.

18. Zavala J., Ramirez W., Reyes A., Bates M. : Angiostrongylosis costaricensis. Primeros casos mexicanos. Rev. Invest. Clin. (Mex.), 1979, 26, 389-394. 